\title{
Comparative Study of Bot \& Ham Models of Public Private Partnership
}

\author{
Nikhil Kumar ${ }^{1}$, Akash Agrawal ${ }^{2}$ \\ PG Student ${ }^{1}$, Assistant Professor ${ }^{2}$, Department of Civil Engineering ${ }^{1,2}$ (Construction Engineering \& \\ Management), Sam Higginbottom University of Agriculture, Technology \& Sciences, Allahabad (Prayagraj), \\ Uttar Pradesh, India,Email:nikhil4943@gmail.com², akashagrawal019@gmail.com²
}

\begin{abstract}
Public Private Partnership has really been a boost in the infrastructural development of the nation in almost every sector but primarily major share is contributed by roads and highway development. To make PPP a successful method certainly a best possible model should be adopted in Model Concessionaire Agreement between public and private party. In this paper case study has been made between two such projects viz. Delhi Gurgaon Expressway and Bharatmala Expressway which are build over BOT and HAM models respectively. Both of these models and more such models in PPP play a significant role in careful allocation of scare productive resources in construction work. With the upcoming of the HAM model which is a mix of both BOT and EPC models, the financial burden is now shared in 40:60 ratios between private and public party respectively, which encourages more private parties to enter into the MCA in PPP. In any infrastructural development work, funding of capital is utter important and since these are very limited with government and they have other important work where capital investment is required. So, PPP provides a very good platform where funding issue is not a big problem, since private party see it as a very good opportunity to invest in as well as their capital recovery from the project is also quite certain and fruitful. This comparative study highlights all the pros \& cones in both of these widely used PPP models and it really gives concessionaire and public party a wide variety of models to pick from depending upon circumstances.
\end{abstract}

Index Terms- HAM; BOT; Concessionaire; Model Concessionaire Agreement; Delhi Gurgaon Expressway.

\section{INTRODUCTION}

Public Private Partnership (PPP) plays a very important role in the infrastructural development of the nation. It consists of various models which could be adopted for the contractual agreement between the concessionaire and private party. These models play a key role because it determines the type role which would be shared between the private and public party. So, before going for the actual construction work a proper model should be adopted which would facilitate a smooth flow between both the parties. So, it depends on the government that what type of model they incorporate and that depends on the kind of work which they undertake. For example, if we take the construction of road network then there are many models which could be used but for the sake of interest of the private company a suitable model should be used which would help to share the different kinds of risk and help to complete the work on time.

So, PPP has made a significant contribution towards the development of the country. The kind of idea that is put behind the concept of PPP is really beneficial. As we know that the capital investment is really a big issue if we consider any infrastructural development plan, so the idea of funding by the investors seeking an opportunity of profit really attracted them to invest in these growing and profitable construction development work.
The overall concept of PPP has really benefited India in the infrastructural growth in the last few decades. This has also lessened the burden of finance over the Indian Economy and has enabled the government to use the money in more people concerned projects. In this paper study has been made over the two PPP models which are HAM and BOT projects which are both highway projects. Both of these models have got significance in the way projects are being executed. Both of them have got some advantages and disadvantages over the other whether it is about risk allocation, financial burden, land clearance etc. So, it depends upon the government for the kind of model concession agreement that is being signed between the concessionaire and the public party. Apart from these models there are several other models which are equally important and useful. In all those models difference lies in the way projects are handled, designed, built, financed, risk allocated, land clearance, revenue collection rights etc. So, in this paper focus would be given to only HAM \& BOT modes of PPP.

\section{PROS AND CONS OF STATE \& MARKET}

In the age of liberalization state has realized that optimum utilization of resources is not possible without

the active cooperation of private sector. So, both of them must work together for the speedy growth of the nation.

$>$ Since state has following advantages: -

a) Enjoy huge amount of credibility among citizens. 


\section{E-ISSN: 2321-9637 \\ Available online at www.ijrat.org}

b) Ability to raise resources.

c) Ensuring sustainable \& equitable growth.

$>$ However, state has following weakness: -

a) Red Tapism, in which take months and years to start new business because of many clearances.

b) Time \& cost overruns.

c) Politicization of development process.

$>$ However, markets have following advantages: -

a) Efficient utilization of resources.

b) Provide quality goods \& services to citizens.

c) Ensure competitive price mechanism.

d) Introduce innovations.

$>$ However, market has following weakness: -

a) Creation of monopoly.

b) Crony capitalism, there is unholy excess between businessman and politician.

c) Profit motive.

d) Negative externalities, focus is only on profit making

\section{PUblic PRIVATE PARTNERShIP IN INDIA}

After the successful implementation of PPP all over the world, India was not so behind to realize the importance of PPP and in the first decade of $20^{\text {th }}$ Century, we implemented the series of various models of PPP in the urban planning and infrastructural development. From the figure 1 it is clear that the PPP in road sector has seen a grater number of participation and it is nearly $53.4 \%$, after which we have Railways, Ports, Healthcare, Energy, Education, Airports, Urban Developments, and Tourism (Bramhankar, 2018).

Though every sector is important but the bulk of participation is in the field of road development program. It is because there is a huge scope of revenue generation and whichever private party woks under the model concessionaire agreement during particular

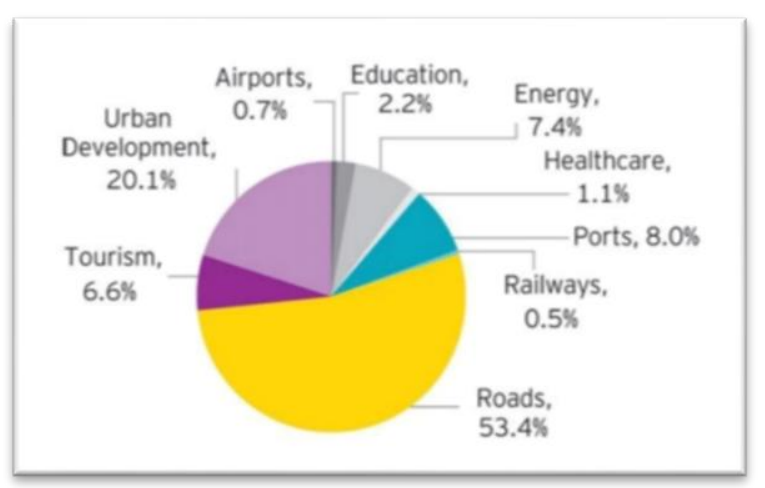

Figure 1: - Sector wise PPP projects in India concession period enjoys huge share of benefit through toll collection and more.

\section{HAM FOR IMPLEMENTING HIGHWAY PROJECTS}

The Competent Authority considered the proposal of HAM on 27th Jan 2016. Now National Highway projects are also to be implemented on the HAM as one of the modes of delivery. This model is a variant of PPP and may be adopted for projects.

Some silent features of the Model are as follows: -

- For example, a project with a cost of Rs 1000 crores taken up through the above model would have the following basic parameters.

- Project Cost- Rs 1000 crores

- Construction Support by Authority- Rs 400 crores

- Balance Project Cost required to be funded by the concessionaire- Rs 600 crores.

- Debt and Equity requirement (assuming a 70:30 Debt: Equity ratio)

a) Equity required Rs 180 crores (as against Rs 300 crores under the conventional BOT model)

b) Debt required Rs 420 crores (as against Rs 700 crores under the conventional BOT model)

- The project implementing Authority shall source the expenditure requirements- for the construction period to the tune of $40 \%$ of the project cost and also for the operations periods for the annuity payments from the resource available with them including a) the budgetary allocation and b) market borrowing as permitted by Ministry of Finance.

- It is clarified that BOT mode still remains the default and the preferred mode of delivery for national highway projects.

\section{COMPARISION OF CASE STUDY OF BOT \& HAM MODELS}

\subsection{Delhi Gurgaon Expressway}

It is the one of the busiest $28 \mathrm{~km}$ expressways in India and is handling nearly 200,000 PCUs per day. It lies on NH-48 which connects Delhi to Gurgaon and is a part of the Golden Quadrilateral (GQ) Project. So, as a part of this project it consists of conversion of busy section into a 6/8 lane from earlier 4/6 lane. This expressway was so worth investing that the bidder agreed to pay Rs. 62 Crore, as a negative grant to NHAI in order to get the contract. 


\section{E-ISSN: 2321-9637 \\ Available online at www.ijrat.org}

This is one of the important BOT highway projects and was awarded to (DSC) DS Construction Ltd and

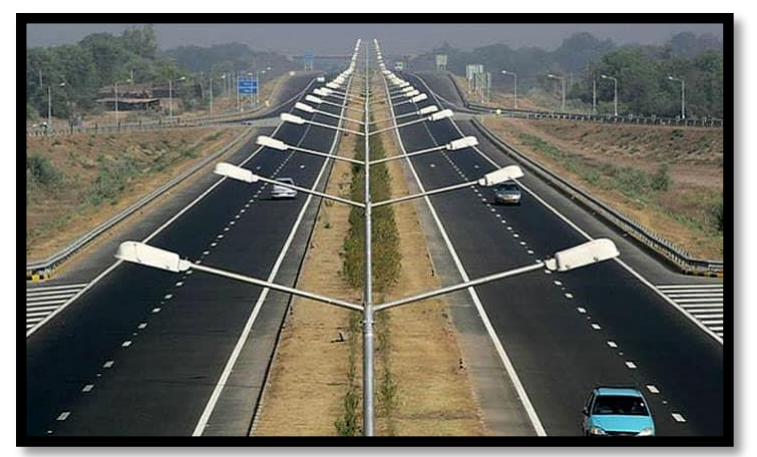

Jaypee Industries to maintain, construct, operate, finance and design the highway for a concession period of 20 years and it was finally opened for public use on $23^{\text {rd }}$ January 2008 . This is one of the successful implementations of the PPP in highway construction and development. This expressway has been successfully implemented by the mutual cooperation and working of National Highways Authority of India (NHAI), Central Road Research Institute (CRRI), Haryana Urban Development Authority (HUDA) and Delhi Development Authority (DDA).

Figure 2: - Delhi Gurgaon Expressway

During the duration of concession period which is 20 years the concessionaire is allowed to collect the toll taxes which has been previously agreed upon. Concessionaire created a Special Purpose Vehicle for successful implementation and coordination of the Project.

\subsection{Bharatmala Expressway Project}

Since the introduction of HAM model by Shri Nitin Gadkari on 27th Jan 2016 so many HAM projects have been taken up by the concessionaire in highway development sector. Among which Bharatmala Expressway is also an ongoing project which will be constructed on several phases and is expected to get completed till July 2022. Some of the cities through which this expressway would pass includes Mumbai, Kolkata, Amritsar, Pune, Raipur, Nagpur, Hyderabad, Delhi, Lucknow, Chennai, Ranchi.

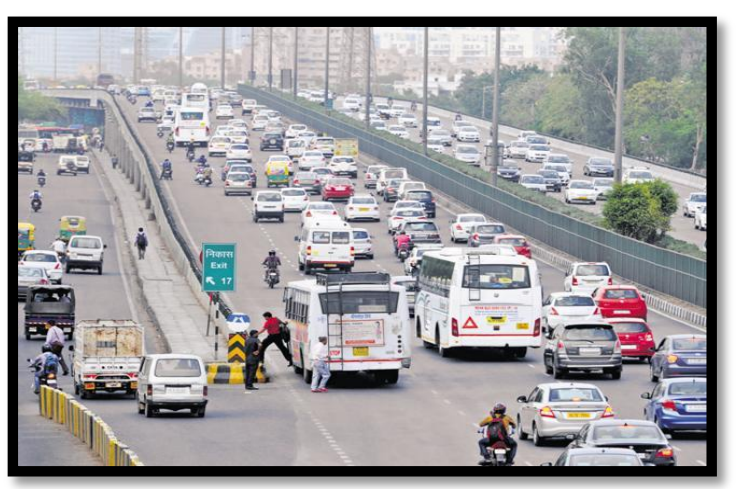

Figure 3: - Bharatmala Expressway

For the construction of Bharatmala Expressway for a total of $25,000 \mathrm{~km}$ for a period of five years government has given his approval for its successful implementation. NHAI and Road Transport and Highways Ministry will play a vital role in the successful execution of the project.

\section{CONCLUSION}

We conclude from the two models that both have some pros and cons related to them but compared to BOT model, HAM turns out to be a better alternative for the highway construction project. Here, the risk allocation is minimum and financial burden is also shared to a great extent to both public and private and moreover such HAM projects have better future.

Since after the launch of so many HAM projects are under construction and many more would come up in near future. The government is taking every possible step to ensure HAM becomes the first priority for the highway construction and development across the country. The main reason which has made HAM so popular is its ability to handle risk with regard to financial management. In this aspect government is liable to pay only $40 \%$ of the overall cost in five installments and the rest $60 \%$ is the burden of the private party. They can raise the fund by means of equity, loans or any debt and the financial support is given to them only when a certain target is achieved in due course of time otherwise penalty would be imposed over them (Daulatabadi, 2017).

Both of these projects and many more are live examples of successful implementation of PPP and the right policy making by the government. Both HAM \& BOT models of PPP suits very well in the highway development but apart from these there are many other successful models which can't be neglected and their role in other sectors like railways, airports, ports and many other. In few coming decades PPP would certainly take India to a next level of infrastructural development in order to boost Indian economy.

\section{FUTURE SCOPE}

From the detailed case study of the both BOT \& HAM models we infer that there is further scope of inclusion of another model and at the same time the current PPP model could also be reformed to PPPP which is Public Private Peoples Partnership which would be more answerable to the stakeholder since in this partnership people will be involved in the decision making and will be concerned so that there is less chance of an possible corruption. This would result in the generation of a better proposal of any construction work. Moreover, from my study I would also like to state that, under this PPPP a certain model could be developed which would encourage more private parties and investors to invest into the highway construction project. Since there is a great chance of corruption which tends to shatter the belief of people in such projects and over government. So, any 


\section{Available online at www.ijrat.org}

proposed model would certainly boost up the construction process and would ultimately lead to the rapid development of the nation. Any such proposal which has potential to demise concessionaire risk and attack more of investors to invest in such projects would lead to ultimate growth.

\section{REFERENCES}

[1] Tiong, Robert L.K. (1990), "Comparative Study of BOT Projects", Journal of Management in Engineering, Volume 6, Issue 1, DOI: 10.1061/(ASCE)9742-597X (1990)6:1(107), pp. 107-122.

[2] Broadbent Jane, Laughlin Richard (2003), "Public Private Partnership: an introduction”, Accounting, Auditing \& Accountability Journal, Volume 16, Issue 3, DOI: 10.1108/09513570310482282, pp. 332-341.

[3] Tang LiYaning, Shen Qiping and Cheng L.W. Eddie (2010), "A review of studies on PublicPrivate Partnership projects in the construction industry", International Journal of Project Management, doi:10.1016/j.ijproman, pp 683694.

[4] He Jun (2012), "Study for Integrated Risk Management of BOT Projects", International Conference on Civil Engineering and Urban Planning, Yantai China, DOI: 10.1061/9780784412435.106, pp. 594-599.

[5] S.K. Harisankar and G. Sreeparvathy(2013), "Rethinking Dispute Resolution in PPP for Infrastructure Development in India",Journal of Infrastructure Development, Volume 5, Issue 1, https://doi.org/10.1177/0974930613488292, pp. 21-32.

[6] Saussier S. (2013), "Public-Private partnerships", Journal of Economic Behavior \& Organization, Volume 89, doi.10.1016/j.jebo.2012.05.001, pp. 143-144.

[7] Telang Vidya and Kutumbale Vishakha (2014), "Public Private Partnerships in India", Research Front, Volume 2, Issue 4, pp 13-25.

[8] Vadali Nandita, Tiwari Prakash Anand and A. Rajan Thillai (2014), "Effect of the Political Environment on Public Private Partnership Projects: Evidence from Road Projects",Journal of Infrastructure Development, Volume 6, Issue 2, DOI: 10.1177/0974930614564651, pp. 145-165.

[9] R., Akhmetshina E. and N., Mustafin A. (2014), "Public-private partnership as a tool for development of innovative economy", International Conference on Applied Economics, Russia, doi.org/10.1016/S2212-5671(15)00609-7, pp.35-40.

[10] Khmel Vialeta and Zhao Shengchuan (2015), "Arrangement of financing for highway infrastructure projects under the conditions of Public-Private Partnership", International Association of Traffic and Safety Sciences (IATSS) Research, Volume 39, Issue 2, http://dx.doi.org/10.1016/j.iatssr.2015.05.002, pp. 138-145.

[11] Gopalkrishna Nagesha and Karnam Gayithri (2016), "Are the Indian National Highway PPPs More Efficient than Non-PPPs? An Empirical Analysis through Data Envelopment Analysis", Journal of Infrastructure Development, Volume 8, Issue 1, doi.10.1177/0974930616648819, pp. 2735.

[12] K. Ankit, Chavan Gaurav and Jadhav Vivekanand (2017), "Study of different Public-Private Partnership (PPP) Model for the Road Infrastructure", International Research Journal of Engineering and Technology (IRJET), Volume 4, Issue 3, pp. 2410-2412.

[13] Daulatabadi, A.P. and Raisinghani, M. (2017), "Model Concession Agreement (MCA) for Highway PPP Projects in India: Evolution and its Various Forms", International Journal for Research in Engineering Application \& Management (IJREAM), Volume 3, Issue 9, DOI: 10.18231/2454-9150.2017.0058, pp. 49-52.

[14] Prabhudesai1 Vimlesh and Sarode, G. Nandkishor (2017), "Public Private Partnership (PPP) and its Evolution - A Conceptual Framework", International Journal of Scientific Research and Management (IJSRM), Volume 5, Issue 7, DOI: 10.18535/ijsrm/v5i7.32, pp. 6070-6074.

[15] Sawant K.M., Kadam Kartik Et al. (2018), "Analysis of Hybrid Annuity Model (HAM) For PPP in Highway Project", International Journal for Scientific Research \& Development, Volume 6, Issue 2, pp. 3464-3466.

[16] Keers M.B.B. and Fenema.V.C.P (2018), "Managing risks in public-private partnership formation projects", International Journal of Project Management, Volume 36, Issue 6, https://doi.org/10.1016/j.ijproman.2018.05.001, pp. 861-875.

[17] Bramhankar C. Abhishek (2018), "Public Privare Partnership for Road Sector in India: An Overview", Volume 5, Issue 1, DOI: 10.21884/IJMTER.2018.5018.SQL1O, pp. 108112.

[18] Patwardhan, A. V. (2016): Hybrid Annuity Model (HAM) for PPP Projects, NPPO Digest \#06, National Public Procurement Observatory, CUTS Institute for Regulation \& Competition, New Delhi.

[19] Sonawane A.N. and Pimplikar S.S. (2017), "Comparative Study of Public Privet Partnership (PPP) \& Engineering, Procurement, Construction (EPC) Contracts", International Journal of Advance Scientific Research and Engineering Trends, Volume 2, Issue 2.

[20] Garg Swapnil and Mahapatra Diptiranjan (2018), "Hybrid annuity model: Hamming risk allocations in Indian highway public-private partnerships", John Wiley \& Sons, Ltd. DOI. 10.1002/pa.1890. 